\title{
Choice of law in defamation and the regulation of free speech on social media:
}

\section{Nineteenth century law meets twenty-first century problems}

Author's final version. For publication in David Mangan and Lorna Gillies (eds), The Legal Challenges of Social Media (Elgar, 2017)

\section{Alex Mills*}

\section{Abstract}

Social media networks have democratized the power of mass communication. One less laudable consequence of this development is, however, that individuals are at a much greater risk of committing defamation than existed under traditional media, which would generally exercise editorial control. The legal problems associated with defamation on social media are made more complex by the fact that through the internet in general and social media in particular communications will readily cross borders. Where a communication crosses borders, the question of the applicable law arises - whose law should govern whether the communication gives rise to an actionable claim for defamation? This is a problem which is addressed by rules of private international law, in particular through choice of law rules. This chapter examines the rules which apply in the English courts to determine which national law governs cross-border claims in defamation, considering whether a special rule should apply for online defamation, and whether the problems raised by social media require further specialized regulation. In so doing, it also analyses why the applicable rules, which were

\footnotetext{
* This chapter was originally presented at a conference on 'The Legal Challenges of Social Media to Freedom of Expression', held at the University of Leicester in December 2013, and thanks go to the conference organisers and participants, as well as an anonymous referee. With permission, it draws partially on work previously published by the author as 'The Law Applicable to Cross-Border Defamation on Social Media: Whose Law Governs Free Speech in 'Facebookistan'?' (2015) 7 Journal of Media Law 1 <www.tandfonline.com/doi/abs/10.1080/17577632.2015.1055942>.
} 
developed in the nineteenth century, have proven so resistant to modernisation in the face of the challenges of the twenty-first century.

\section{Introduction}

Social media networks have democratized the power of mass communication, an exhilarating development which challenges the control of governments and traditional media magnates over the spread of new ideas. In so doing, these new forms of communication have also (unsurprisingly) created new legal problems, perhaps most prominently in relation to cyberbullying, hate speech, and the promotion of terrorism. Another evident consequence of these developments is that individuals are at a much greater risk of committing defamation than existed under traditional media, which would generally exercise editorial control where individuals were publishing material to a wide audience. This risk is particularly strong because the general style of communication online through social media is informal and casual, and thus the impact of a communication will not necessarily be judged as lightly as it may have been intended (or hoped). ${ }^{1}$ It is true that not all online communication is intended to be ephemeral - a much valued feature of social media is the rise in 'citizen journalism'. In general, however, there is a mis-match between the popular perception of online communications, often likened to 'chatting', and the legal perception, which is that any tweet or Facebook post is as much a publication as a traditional newspaper article. ${ }^{2}$

\footnotetext{
${ }^{1}$ The Court in McAlpine v Bercow [2013] EWHC 1342 (QB), for example, was unpersuaded that the inclusion of the words '*innocent face*' as part of the tweet concerned indicated anything other than insincerity. The online and casual context of a communication may, however, be taken into consideration in interpreting the words used: see eg Thompson v James [2013] EWHC 515 (QB), [270].

${ }^{2}$ Further discussion on this point is found in David Mangan, Chapter XX in this volume.
} 
The legal problems associated with defamation on social media are made more complex by the fact that through the internet in general and social media in particular communications will readily cross borders. Where a communication crosses borders, the question of the applicable law arises - whose law should govern whether the communication gives rise to an actionable claim for defamation? All defamation law seeks to balance the rights of speakers with the rights of reputation of those about whom they speak - but what if the speaker and their subject live in different jurisdictions which strike this balance in different ways?

This is a problem which is addressed by rules of private international law, in particular through choice of law rules. This chapter examines the rules which apply in the English courts to determine which national law governs cross-border claims in defamation, considering whether a special rule should apply for online defamation, and whether the problems raised by social media require further specialized regulation. It also explains why the applicable rules, which were developed in the nineteenth century, have proven so resistant to modernisation.

\section{The double-actionability rule}

The traditional choice of law rule in tort in English law - which still applies to choice of law in defamation today - was established in 1870, in Phillips $v$ Eyre. ${ }^{3}$ This case arose out of claims against Edward John Eyre, who served as colonial Governor of Jamaica. Faced with an uprising known as the Morant Bay Rebellion, he used brutal force to suppress the protestors, then passed a law giving himself immunity. Eyre's conduct became a cause

\footnotetext{
${ }^{3}$ Phillips v Eyre (1870) LR 6 QB 1. See further generally Peter Handford, 'Edward John Eyre and the Conflict of Laws' (2008) 32 Melb UL Rev 822.
} 
célèbre, and although no criminal proceedings were forthcoming when he returned to

England, parties involved with the rebellion brought civil proceedings for assault and false imprisonment against him. ${ }^{4}$

Although this was a private law claim, it evidently had an intensely public character and context. These somewhat unusual facts gave rise to a somewhat unusual choice of law rule.

The court held:

As a general rule, in order to found a suit in England for a wrong alleged to have been committed abroad, two conditions must be fulfilled. First, the wrong must be of such a character that it would have been actionable if committed in England ... Secondly, the act must not have been justifiable by the law of the place where it was done. ${ }^{5}$

In so doing, the court hybridized two traditional influences on choice of law in tort - the first viewing tort law as comparable to criminal law, ${ }^{6}$ and thus as a matter of public law governed by the law of the forum, and the second viewing tort law as a matter of territorial conduct regulation. ${ }^{7}$ What is perhaps unique about this rule is that it insists on the application of both principles, requiring that liability be established under both sets of laws, the lex fori (law of the forum) and the lex loci delicti (law of the place of the tort) - thus it is widely known as the rule of 'double-actionability'.

\footnotetext{
${ }^{4}$ Lead counsel for the claimants was John Richard Quain, a fellow of University College in London, after whom, together with his brother, the Quain professorships at UCL are named.

${ }^{5}$ Phillips v. Eyre (n 3) 28. The claims failed because this second requirement was defeated by Eyre's immunity.

${ }^{6}$ As the Law Commission and Scottish Law Commission expressed it: the law of tort and delict was formerly seen, much more than it is today, as having a punitive rather than a compensatory function. As such it was more closely allied to criminal law, an area of the law where there is no question of a court in this country applying anything other than the domestic law of England or Scotland

Joint Report of the Law Commission (No 193) and the Scottish Law Commission (No 129) on 'Private International Law: Choice of Law in Tort and Delict' (1990) [2.6] <www.bailii.org/ew/other/EWLC/1990/193.pdf> accessed 3 June 2016.

7 See further eg Symeon Symeonides, 'Rome II and Tort Conflicts: A Missed Opportunity' (2008) 56 Am J Comp L 173, 188.
} 
The rule established in Phillips $v$ Eyre has received two significant further developments by the courts. In Boys $v$ Chaplin,${ }^{8}$ the House of Lords held that exceptionally the doubleactionability requirement could be disapplied in favour of the exclusive application of English law. While not quite expressed in this way, arguably the real reasoning behind this decision was that the two parties were English, and the key issue in the proceedings was the question of the allocation of loss between those parties. The court thus accepted the influence of a third idea of tort law as concerned with loss-distribution, principally developed in the United States, ${ }^{9}$ and indeed the court cited to the leading US authorities which had developed that idea. ${ }^{10}$ In Red Sea Insurance Co v Bouygues $S A,{ }^{11}$ the Privy Council held that a claim in tort brought before the courts of Hong Kong arising out of problems with construction work in Saudi Arabia could be governed exclusively by the law of Saudi Arabia - thus, by the law of the place of the tort rather than the law of the forum. The court held that this exception should be based on whether the law of the place of the tort had the 'most significant relationship' with the claim. ${ }^{12}$

These developments left the traditional common law choice of law rule in tort in a somewhat confused position, at least when it comes to identifying the underlying principle or approach - perhaps reflecting the range of competing views about the function of tort law itself. While the starting point remains the rule of double-actionability, which suggests a combination of viewing tort as having a public regulatory function as well as being concerned with conduct regulation, flexible exceptions may point exclusively toward the law of the place of the tort or the common law of the parties, suggesting a concern with loss distribution. Which of these

\footnotetext{
${ }^{8}$ Boys v Chaplin [1969] 2 All ER 1085.

${ }^{9}$ See Symeonides (n 7) 188.

${ }^{10}$ [1969] 2 All ER 1085, $1102 \mathrm{ff}$.

${ }^{11}$ Red Sea Insurance Co v Bouygues SA [1995] 1 AC 190.

12 ibid 206.
} 
approaches is adopted - which principle prevails - is largely left to the courts to resolve on a case-by-case basis.

As noted above, this complex double-actionability rule continues to apply to claims for defamation brought before the English courts today, which may suggest a similar uncertainty regarding the function of defamation law. But the significance of this fact needs to be understood within a broader context, in which defamation has been specifically excluded from both UK and EU reforms to choice of law in tort. The following section discusses these reforms, and considers why it was viewed as inappropriate for them to encompass choice of law in defamation and why no alternative reformed rule has been adopted.

\section{Reforms to choice of law in tort}

\subsection{Private International Law (Miscellaneous Provisions) Act 1995}

The double-actionability rule provides, at least as a starting point, that English law should be applied to any tort, regardless of where in the world it was committed. It has been subject to widespread criticism as being 'chauvinist' and 'parochial'. ${ }^{13}$ Another way of expressing this criticism is that the 'public' function of tort law, which had historically justified the application of the lex fori by analogy to criminal law, was increasingly challenged. The judicial modification of the rule through the development of a flexible exception did not do enough to address these concerns, which led finally to a 1995 UK statutory reform. As noted above, defamation was excluded from this statutory regulation (section 13). A brief

\footnotetext{
${ }^{13}$ See eg Joint Report of the Law Commission (No 193) and the Scottish Law Commission (No 129) (n 6) [2.7].
} 
explanation of the approach of the Act is still, however, helpful if we are to understand the reasons for this exclusion (discussed further in section 3.3 below).

The Act essentially established a two-stage test for determining the law applicable to a tort. Section 11(1) established the general rule, 'that the applicable law is the law of the country in which the events constituting the tort or delict in question occur'; offering further guidance in section 11(2) on how that law should be determined where 'elements of those events occur in different countries'. Essentially, the basic rule adopted is a lex loci delicti rule - the law of the place of the tort. The second stage of the test, set out in section 12, provided for a flexible exception, under which a different law may be applied if this appears substantially more appropriate on the basis of a comparison of the connecting factors between the tort and different countries. In practice the courts have tended to use this exception principally for cases in which the relationship between the parties is centred around a different legal order. In Edmunds v Simmonds, ${ }^{14}$ for example, two English parties were involved in a car accident in Spain while on holiday there. The court found that English law should be applicable, emphasising that both parties were English, and that most of the damages were suffered in England.

Two key features of the 1995 Act might therefore be identified. The first is that it abandons any prioritisation of the law of the forum, and thus rejects any 'public' dimension to choice of law in tort. ${ }^{15}$ The second is that it does not strictly decide between a conduct regulating or loss distributing approach. While the former is adopted as the most general rule, through the application of the lex loci delicti, the flexible exception allows the court to determine that a

\footnotetext{
${ }^{14}$ Edmunds v Simmonds [2001] 1 WLR 1003.

${ }^{15}$ Although under section 14(3)(a)(i) the courts retain a discretion to refuse the application of foreign law which is contrary to forum public policy.
} 
dispute, or an issue in a dispute, is more appropriately regulated by a different law, including where that issue concerns questions of loss allocation between parties whose relationship is centred in a different legal order.

\subsection{The Rome II Regulation (2007)}

Regulation of choice of law in tort has long been on the agenda of the European Union. The Rome II Regulation on the law applicable to non-contractual obligations ${ }^{16}$ was finally enacted on 11 July 2007, coming into force from 11 January 2009 and applying to events which arose after that date. ${ }^{17}$ Defamation was, however, excluded from the scope of the Rome II Regulation, under Article 1(2)(g), alongside violations of privacy. ${ }^{18}$ Although not the main focus of this chapter, it is notable that the English Court of Appeal recently recognised a tort of 'misuse of private information'. ${ }^{19}$ The recognition was for jurisdictional purposes, but the court suggested that this may also affect the characterisation of the cause of action in the context of choice of law. This new cause of action has developed from the law on breach of confidence, which is generally classified as restitutionary rather than delictual. ${ }^{20}$ If, however, it has indeed evolved into a tort, claims for misuse of private information are likely to be covered by the Rome II Regulation exclusion, and fall within the scope of the 1995 Act.

The exclusion of defamation and privacy from the Rome II Regulation is intended to be temporary, and Article 30(2) of the Regulation required the Commission to carry out a study

\footnotetext{
16 Regulation (EC) No 864/2007 of the European Parliament and of the Council of 11 July 2007 on the law applicable to non-contractual obligations ('Rome II') [2007] OJ L 199/40.

17 The date of commencement of the Regulation was unclear until settled in C-412/10 Homawoo v GMF Assurances SA (CJEU, 17 November 2011).

${ }^{18}$ Claims in 'privacy' are not excluded from the Private International Law (Miscellaneous Provisions) Act 1995. Although a tort of 'breach of privacy' has not traditionally been part of English law, a claim may be brought before the English courts if it is governed by a foreign law which recognises such a tort.

${ }^{19}$ Google Inc v Vidal-Hall [2015] EWCA Civ 311 (appeal to the Supreme Court pending).

${ }^{20}$ Kitechnology BV v Unicor GmbH [1995] IL Pr 568.
} 
on choice of law in the context of privacy and defamation no later than 31 December 2008, duly completed in February 2009 and consisting largely of a comparative analysis of existing choice of law rules applicable to privacy and defamation in the Member States. ${ }^{21}$ Despite prompting from the European Parliament, ${ }^{22}$ as discussed further below, the Commission has not yet taken any further steps in the matter.

Although not applicable to defamation, the approach of the new general choice of law rule in tort, set out in Article 4 of the Regulation, is again worth noting. Article 4(1) specifies that a tort is generally governed by the law of the place of the tort, which is defined as the place in which direct damage is suffered. Article 4(2) specifies that this general rule is displaced in favour of the law of common habitual residence of the parties, should they have one. Finally, Article 4(3) specifies that if another law is 'manifestly more closely connected' than the law chosen under Article 4(1) or (2), which may particularly be the case where the parties have a pre-existing contractual relationship governed by a different law, then that law applies instead. The effect is a rule which combines a number of the elements and considerations examined in this chapter, not greatly dissimilar to that adopted under the 1995 Act in the United Kingdom - accepting and mediating uncertainly between the possibility of giving effect to the law of the place of the tort or the law common to the parties (or another law), but excluding any necessary role for the law of the forum, as is provided for under the traditional common law double-actionability rule.

\footnotetext{
${ }^{21}$ Commission, 'Comparative Study on the Situation in the 27 Member States as regards the Law Applicable to Non-Contractual Obligations Arising out of Violations of Privacy and Rights relating to Personality' (Final Report) JLS/2007/C4/028 (February 2009) 〈http://ec.europa.eu/justice/civil/files/study_privacy_en.pdf> accessed 3 June 2016.

${ }^{22}$ See, eg, European Parliament, 'Question for Written Answer to the Commission by Cecilia Wikström (ALDE) - Subject: Inclusion of Libel Law under Rome II' [2014] OJ C 6E/1, p 191 (English version) $<$ www.europarl.europa.eu/sides/getDoc.do?type=WQ\&reference=E-2013-002703\&language $=E N>$ accessed 3 June 2016.
} 


\subsection{The exclusion of defamation from statutory reform}

The history examined above leaves us with a simple fact - defamation has thus far been excluded from reforms in the field of choice of law in tort, leaving it governed by a doubleactionability rule which has been widely criticised for being parochial and chauvinist. This section explores two possible explanations for this exclusion - one pragmatic, and the other a point of principle.

The pragmatic explanation is that the double-actionability rule works in favour of English media organisations. The effect of the double-actionability rule is that the defendant gets the benefit of two sets of defences if proceedings are brought against them in England in relation to allegations of defamation in a foreign state. For English media organisations, this essentially means that, at least so far as proceedings against them in England are concerned, English law acts as a ceiling of liability, but does not exclude the possibility that liability may indeed be diminished further if they publish in a foreign jurisdiction (such as that of the United States) which places greater emphasis on freedom of speech. To put this another way, double-actionability effectively means that where defamation proceedings are brought in England relating to foreign conduct, whichever system of law has the higher standard of free speech is applicable. $^{23}$

The point of principle is that the scope of the law of defamation is part of what defines the contours of a legal system's rights of free speech, including political discourse. The reform efforts in the 1995 Act and the Rome II Regulation both shifted tort law away from its historic associations with criminal law (and the application of the lex fori), toward viewing it

\footnotetext{
${ }^{23}$ While English substantive defamation law is generally considered to be pro-claimant, English choice of law rules for defamation may thus curiously be considered pro-defendant.
} 
more as purely private law, subject to the same considerations of legal pluralism between states which justify choice of law rules more generally. ${ }^{24}$ The continuation of the doubleactionability rule in the context of defamation may thus be a defensible reflection of the distinct public implications of defamation law. The on-going application of a nineteenth century choice of law rule to defamation might be considered not anachronistic but appropriate on the basis that the law of defamation distinctively engages public regulatory interests in a way which is consistent with (otherwise arguably outmoded ${ }^{25}$ ) nineteenth century understandings of the function of tort law in general.

The evident risk of insisting on the application of English law in every case (at least as a minimum standard) is an over-application of English policies, exporting or projecting them unreasonably by applying them to a foreign context. It is not clear, for example, why an English media organisation which publishes a newspaper distributed exclusively in a foreign state should be able to rely on the protection (at least presumed) of English law under the double-actionability rule, if sued in England for defamation. While these questions may be difficult, a choice of law rule which engaged with the issue of which political community was targeted or affected by a communication would seem a more sensitive response to the problem of determining which law should govern disputes concerning cross-border defamation.

\footnotetext{
${ }^{24}$ See generally Alex Mills, The Confluence of Public and Private International Law (CUP 2009) 5.

${ }^{25}$ But see eg John C. P. Goldberg and Benjamin C. Zipursky, 'Torts as wrongs' (2010) 88 Tex L Rev 917; Matthew Dyson (ed), Unravelling Tort and Crime (CUP, 2014).
} 


\subsection{A European proposal?}

In May 2012, the Committee on Legal Affairs of the European Parliament proposed (as an amendment to the Rome II Regulation) a new choice of law rule which would offer a clearly more sophisticated tool than the blunt double-actionability rule, providing that:

1. The law applicable to a non-contractual obligation arising out of a violation of privacy or rights relating to the personality, including defamation, shall be the law of the country in which the most significant element or elements of the loss or damage occur or are likely to occur.

2. However, the law applicable shall be the law of the country in which the defendant is habitually resident if he or she could not reasonably have foreseen substantial consequences of his or her act occurring in the country designated by paragraph 1.

3. Where the violation is caused by the publication of printed matter or by a broadcast, the country in which the most significant element or elements of the damage occur or are likely to occur shall be deemed to be the country to which the publication or broadcasting service is principally directed or, if this is not apparent, the country in which editorial control is exercised, and that country's law shall be applicable. The country to which the publication or broadcast is directed shall be determined in particular by the language of the publication or broadcast or by sales or 
audience size in a given country as a proportion of total sales or audience size or by a combination of those factors. ${ }^{26}$

The public policy defence (already established under Article 26 of the Rome II Regulation) would offer a safety net to this rule, permitting the continued application of the legal standards of the forum where the foreign laws are contrary to fundamental values.

While European regulation of these issues is not necessarily a desirable prospect given the different traditions of free speech protection in the various Member States, ${ }^{27}$ this proposal certainly represented an effort to engage with the competing policy issues and concerns which is far more sophisticated than the double-actionability rule. That is not to say that the proposed rule cannot be subject to criticism. Under subsection (1), the rule provides for the possibility that the law of the place of the loss or damage might apply, regardless of where the defendant acted, thus risking an over-application of the law of the place where material is received and read. ${ }^{28}$ Under subsection (2), the rule provides that the law of the defendant's own habitual residence might apply, risking an under-application of the law of the place where material is received and read and the claimant's reputation damaged. The concept of the 'reasonable foreseeability' of 'substantial consequences' of the act occurring in the place of damage is relied on to demarcate cases which should fall under the first rule rather than the second, although little guidance is provided as to what these terms might mean. It is not clear that the test of reasonable foreseeability fully engages with the concerns regarding the

\footnotetext{
${ }^{26}$ European Parliament resolution of 10 May 2012 with recommendations to the Commission on the amendment of Regulation (EC) No 864/2007 on the law applicable to non-contractual obligations (Rome II) (2009/2170(INI)) 2013/C 261 E/03, <www.europarl.europa.eu/sides/getDoc.do?type=REPORT\&reference=A72012-0152\&format $=X M L \& l a n g u a g e=E N>$ accessed 3 June 2016.

${ }^{27}$ The significance of this point may, however, be reducing with the increased role of the European Convention on Human Rights and Charter of Rights and Fundamental Freedoms on these issues.

${ }^{28}$ It is not clear whether the damage concerned would be the entire loss or only the loss claimed in the proceedings - the latter would raise greater concerns.
} 
extraterritorial application of the claimant's home law, and the risk that this might have a chilling effect on free speech in other jurisdictions.

For publication of printed matter or broadcast material, the place of most significant damage is presumed to be the place at which the publication was principally directed, which (if not apparent) is presumed to be the place in which editorial control is exercised. ${ }^{29}$ The countervailing risk thus arises that print publishers or broadcasters may unduly benefit from these rules. Publishers directing their publications to more than one jurisdiction are free to establish themselves in a jurisdiction with very strong free speech protection, as it is their (favourable) home law which is presumptively applied. Alternatively, publishers directing their publications principally to a jurisdiction with very strong free speech protection may benefit from the fact that the law of principal publication governs even if a claimant suffers reputational damage through substantial publication in another place. Analysis of the European Parliament proposal thus highlights the difficult and complex balancing of interests involved in this issue - a balance which is arguably even more difficult when publication takes place online or through social media, as discussed in the following sections.

\section{Choice of law in defamation online}

This chapter now focuses its attention on the way that choice of law in defamation operates in the online context, both as a matter of current law and as a matter of possible reform.

\footnotetext{
${ }^{29}$ The concept of a 'principally directed' broadcast has been considered in other contexts by the CJEU - see eg Case C-23/93 TV 10 SA v Commissariaat voor de Media [1994] ECR I-4795.
} 


\subsection{The application of the double-actionability rule}

As examined above, the choice of law rule applicable for questions of defamation which arise before the English courts, including defamation online, remains the common law doubleactionability rule. Defamation online is thus a twenty first century problem which strikingly remains regulated by a nineteenth century choice of law rule. ${ }^{30}$ This rule at least starts from the position that the governing law is both English law and the law of the place of the tort. Fixing a territorial location to a tort is thus an essential part of applying this rule, as it would be for any lex loci delicti rule.

The case law dealing with defamation 'offline' establishes that the location of a tort of defamation, for choice of law purposes, is considered to be the place where the material is received and read. ${ }^{31}$ In applying this rule to online communications, the courts have firmly established in a series of cases that where material is published through the internet, the tort occurs where it is 'downloaded' - that is, at the location of the reader or recipient. ${ }^{32}$ In King $v$ Lewis, ${ }^{33}$ for example, the allegedly defamatory character of text uploaded to a website in California and subsequently downloaded in England would be judged according to English law, as each English download was a publication which occurred in England, and the proceedings only claimed in relation to damage to reputation in England. The fact that material published on the internet may be downloaded almost anywhere in the world may thus, in legal terms, give rise to innumerable publications in different jurisdictions, ${ }^{34}$ each of

\footnotetext{
${ }^{30}$ See, for example, The Bussey Law Firm PC v Page [2015] EWHC 563 (QB).

${ }^{31}$ Church of Scientology of California v Commissioner of Metropolitan Police (1976) 120 SJ 690. See also eg Bata v Bata (1948) 92 SJ 574.

${ }^{32}$ See eg Godfrey v Demon Internet Ltd (Application to Strike Out) [2001] QB 201; Loutchansky v Times Newspapers Ltd (No 2) [2001] EMLR 36.

${ }^{33}$ King v Lewis [2004] EWCA Civ 1329.

${ }^{34}$ There are more 'jurisdictions' than there are states, because many federal systems leave private law regulation to their provinces.
} 
which may be governed by different laws (in conjunction with English law, under the doubleactionability rule). ${ }^{35}$

\subsection{Alternative choice of law rules for online defamation?}

The issue of the applicable law for defamation online thus appears to raise particular problems, or at least particularly serious examples of general problems, and it might thus be suggested that a special choice of law rule should be adopted. ${ }^{36}$ There are a limited number of connecting factors which could be relied on to establish such a rule. A territorial rule could point to the place of damage, the place where the publisher acted, or perhaps the place where the publisher directed their actions. Alternatively, a choice of law rule could point to the home law of the claimant or the defendant, or (as under Article 4(2) of the Rome II Regulation) the law of both if this coincides. However, on closer examination each of these options can easily be subject to criticism.

For cross-border defamation online, any territorial rule pointing to the law of the place of the tort (including the current common law double-actionability rule, which does so in conjunction with the law of the forum) does not appear to be entirely satisfactory from the position of either claimants or defendants. Traditionally under the common law (as examined above), a potentially defamatory communication will be 'located' at the place it is received and read, meaning that a large number of torts may arise in different locations when material is posted online. From the perspective of claimants, this means that a range of different applicable laws might govern a defamation action arising from a single online

\footnotetext{
${ }^{35}$ It should be noted that, unlike the homonymous rule applicable in some US states (discussed below), the 'single publication' rule adopted in the United Kingdom under s.8 of the Defamation Act 2013 only affects the expiry of the time limit to bring proceedings, which runs from the 'first publication' (as defined).

${ }^{36}$ A special jurisdictional rule has been adopted by the CJEU for online defamation, allowing a claimant to sue for worldwide damages in the claimant's own 'centre of interests': Case C-509/09, eDate Advertising v X [2012] QB 654.
} 
communication. Even if a single court can be seised of all these claims, the claimant may still need to prove the content of the applicable law in each place in which their reputation has been damaged to be fully compensated, which may be prohibitively expensive. ${ }^{37}$ This 'fragmentation' of the law governing a tort where it leads to damage in different jurisdictions, known as the 'mosaic effect', ${ }^{38}$ is not unique to communications online, but it is a problem which is particularly acute in this context.

From the perspective of defendants, a territorial rule based on the place of damage seems equally problematic but in a very different way. It is true that a small number of English publications should be reflected in a relatively small damages award based on the application of English law. But any award of damages is likely to lead to the withdrawal of many online publications, as very few such publications make sufficient profit in other jurisdictions to overcome the imposition of damages in relation to even a relatively insignificant publication in England. In addition, a claimant will frequently ask the court for an order enjoining future publication of the defamatory material. ${ }^{39}$ Even if this order is limited to publication in England, compliance with such an order in the online context may well require removal of the material from the internet altogether. The effect of this is that it risks a publication being regulated by the lowest common denominator of free speech protection, at least among states whose judgments will be practically effective against the defendant. To put this another way, a rule based on the place of damage risks leading to an over-projection of the public policy of each state in which the material is published, as each state may effectively restrain the

\footnotetext{
${ }^{37}$ Courts may also be reluctant to presume that foreign defamation law, if unproven, is the same as local law, given its special 'public' function of free speech regulation - see eg National Auto Glass Supplies (Australia) Pty Limited v Nielsen \& Moller Autoglass (NSW) Pty Limited (No 8) [2007] FCA 1625 (Australia); Al-Misnad v Azzaman [2003] EWHC 1783 (QB).

${ }^{38}$ See further, eg, Alex Mills, 'The Application of Multiple Laws under the Rome II Regulation' in John Ahern and William Binchy (eds), The Rome II Regulation on the Law Applicable to Non-Contractual Obligations: A New International Litigation Regime (Brill 2009).

${ }^{39}$ See, for example, s 13 of the Defamation Act 2013.
} 
publication worldwide. Thus, the internet may be viewed not only as a mechanism through which communication travels freely, but also a mechanism through which regulation of that communication may itself be 'communicated' readily across borders. A rule which applied the law of the claimant's place of residence (such as that notably adopted in China in $2010^{40}$ ) would similarly purport to project those standards of free speech protection globally, without regard for the interests and expectations of publishers in other jurisdictions. ${ }^{41}$

A territorial rule based on the place of the defendant's actions would obviously be far more attractive to defendants - the standard of free speech protection which would apply to their communications would (at least generally) be their 'home' law (as it would be more obviously should the choice of law rule select that law directly). From the perspective of claimants, however, such a rule would appear to lead to a problematic under-projection of the public policy of other states. Indeed, any similar US-style ${ }^{42}$ attempt to aggregate all the damage caused by an online communication under a single governing law (whether based on the place in which the material was uploaded, or the first or main place in which it was read, or the place with which the tort is 'most closely connected') would seem to underplay the importance which each legal order attaches to regulating communications within its territory.

\footnotetext{
${ }^{40}$ Law of the People's Republic of China on the Laws Applicable to Foreign-related Civil Relations (2010), English translation by LU Song, China Foreign Affairs University < http://conflictoflaws.net/News/2011/01/PILChina.pdf> accessed 3 June 2016; also available at Lu Song, 'Law of the People's Republic of China on the Laws Applicable to Foreign-related Civil Relations (full text)’ (2013) 1 Chin J Comp Law 185:

Article 46. Infringement via Internet or by other means of personality rights such as right to name, right to image, right of reputation and privacy right are governed by the law of the habitual residence of the victim.

${ }^{41}$ This is similar to the jurisdictional rule adopted by the CJEU in the context of online defamation (see $\mathrm{n} 36$ above), but has quite different effects in the context of choice of law.

42 In the United States, the 'single publication' rule began as a jurisdictional principle, to avoid multiplicity of suits, but has also frequently been interpreted to function as a choice of law rule - since only one tort arises out of a publication, including on the internet, it is considered that there can only be one governing law. Under the Uniform Single Publication Act, applicable in many US states, a single publication in multiple places is considered to constitute only a single cause of action, and courts generally apply the law of the claimant's place of domicile in defamation cases, following the Restatement (Second) of Conflict of Laws, s 150. See Laura E Little, 'Internet Defamation, Freedom of Expression, and the Lessons of Private International Law for the United States' (2012) 14 YB Private Int'l L; Lori A Wood, 'Cyber-Defamation and the Single Publication Rule' (2001) 81 BUL Rev 895.
} 
Choosing the place where the publisher acted, for example, would seem almost inevitably to promote a 'race to the bottom' in protection of reputation terms, with publishers choosing to base their internet operations in the most favourable jurisdiction.

Doubts must also be placed on the helpfulness of a choice of law rule (such as that proposed by the European Parliament in relation to defamation generally, as examined in section 3.4 above) which seeks to resolve these questions by identifying the legal order to which a communication is targeted or directed, whether based on the intentions of the publisher or the actual audience of the communication. ${ }^{43}$ An internet publication may frequently not be targeted to any particular jurisdiction, and it may equally be foreseeable that it will be available to be read in almost any jurisdiction. ${ }^{44}$

A similar analysis might be applied to the adoption of a choice of law rule which looked to the law common to the parties, whether based on nationality, domicile or residence. In cases where the claimant's reputation and the communication nevertheless cross borders, applying the parties' common law would seem to be an over-projection of that law, and an underprojection of the law of the other places of the communication and reputation. If one English party defames another English party in the United States, the application of English law seems to underplay the context and the political community within which this communication takes place.

\footnotetext{
${ }^{43}$ See further eg Csongor István Nagy, 'The Word is a Dangerous Weapon: Jurisdiction, Applicable Law and Personality Rights in EU Law - Missed and New Opportunities' (2012) 8 J Priv Int'l L 251.

${ }^{44}$ See similarly King v Lewis [2004] EWCA Civ 1329 [33]-[34]; Young v New Haven Advocate, 315 F3d 256 (4thCir 2002) (finding for jurisdictional purposes that a publication on the internet was not sufficiently directed toward the forum state). See Little (2012) (n 42).
} 


\subsection{Legal and political indeterminacy in regulating online defamation}

So where does this analysis leave choice of law for online defamation? Two reasons for the failure to adopt a more 'modern' choice of law rule may be highlighted. The first is that, in comparison with most subject areas of law which are regulated by private international law, the law of defamation has a stronger public dimension. It is, indeed, notable that many legal systems deal with defamation through criminal as well as tort law. The public dimension of the law of defamation - the fact that it must balance private reputation rights against the freedom of speech which is considered necessary for a particular political or social order - is part of the explanation for the continued application of the double-actionability rule, which partially preserves the common law's traditional public regulatory perspective on choice of law in tort.

The other main explanation for the continuation of the double-actionability rule is the difficulty in formulating any alternative rule, a difficulty which is exacerbated in the online context. What the above analysis suggests is that the choice of which law should govern cross-border defamation, particularly online, is not a matter of legal 'rationality' but a matter of policy. Favouring the law of uploading means favouring free speech at a global level - the 'race to the top' which will occur as publishers locate and act in the jurisdiction which is most favourable to them. Favouring the law of downloading means favouring reputation protection at a global level - the 'race to the bottom' (in free speech terms) which will occur as claimants bring proceedings in the jurisdiction and based on the law applicable which is most favourable to them. The reason the issue of the law applicable to cross-border defamation (particularly online) is so difficult to 'solve' in legal terms may be that it is not solvable, but rather inherently reflects a contest of competing substantive values. 


\section{Choice of law in defamation on social media}

This chapter now narrows its focus again to social media, considering whether there is anything particular or characteristic about the social media context which suggests a different approach to determining the law which should govern a claim in cross-border defamation.

As discussed in the introduction above, the democratization of mass communication through social media increases the risk of defamation cases arising from social media - there already appears, for example, to be a growing number of cases in the English courts dealing with alleged defamation involving Twitter. ${ }^{45}$ The fact that individuals may carelessly or recklessly be exposed to defamation proceedings through social media does suggest the need to balance the interests of claimants and defendants carefully. In the world of social media, defendants are not necessarily large media organisations, and they will not necessarily have the knowledge or resources to resist challenges to their free speech rights - let alone to do so under foreign law.

Part of the solution to this problem could be the effective 'editorialization' of internet content, through a requirement that operators exercise a censorship function over content posted through their services, making them a more attractive 'target' of litigation (and defender of free speech). ${ }^{46}$ This would, however, impose a significant burden on social media sites, essentially requiring them to act more like traditional media organisations. The

\footnotetext{
${ }^{45}$ Including, for example, Barron MP v Collins MEP [2015] EWHC 1125 (QB); The Bussey Law Firm PC v Page [2015] EWHC 563 (QB); Johnson v Steele [2014] EWHC B24 (QB); Reachlocal UK Ltd v Bennett [2014] EWHC 3405 (QB); Coulson v Wilby [2014] EWHC 3404 (QB); Mole v Hunter [2014] EWHC 658 (QB); Kearns v Kemp \& Anor [2013] EWHC 4093 (QB); Mama Group Ltd v Sinclair [2013] EWHC 2374 (QB); McAlpine v Bercow [2013] EWHC 1342 (QB); Cruddas v Adams [2013] EWHC 145 (QB); McCann v Bennett [2013] EWHC 283 (QB); and Cairns v Modi [2012] EWHC 756 (QB).

${ }^{46}$ As under the Defamation Act 1996, s 1 - see Tamiz v Google [2013] EWCA Civ 68; Kearns v Kemp; Twitter, Inc [2013] EWHC 4093 (QB).
} 
approach adopted in UK regulation recently has thus been quite different - under the Defamation Act 2013, web site providers will generally not be liable for material posted through services they provide, even if they moderate those services. ${ }^{47}$

Many of these issues arise regardless of whether the communication has a cross-border element - the issue of whether social media should be regulated as media arises even if all the actors are within a single state. But particular problems arise where such an element exists, as it easily might for social media communications which readily cross porous national boundaries. As examined above, the basic policy difficulty which presents itself for crossborder online defamation is that localizing the tort through a territorial rule appears both too broad and too narrow. It is too broad in the sense that it extends the application of the legal order which is chosen to cover other territorial places connected to the communication. A territorial rule is also too narrow in the sense that it isolates a single choice of law rule for a communication which is at least partially carried out within a distinct foreign political and legal order. Indeed, applying the law of the place of download leads to the potential application of numerous laws to a single communication, as each place of download potential establishes a distinct tort.

These apparently unsolvable problems invite consideration of a more radical solution. In some contexts, there is an apparent need to localize defamation to a particular state, particularly where it is the party's 'offline' reputation which is at stake, and that reputation is based within a certain territorial community. But it might be questioned whether this is or should always be the case. A characteristic feature of social media is that it permits widespread communication by individuals to an audience which is potentially the world as a

\footnotetext{
${ }^{47}$ Defamation Act 2013, s 5; note also s 10.
} 
whole, but also potentially a defined social group or network. The communication may thus be constrained to a particular 'community' which only exists online. In order to avoid the apparent arbitrariness of applying territorial rules, and the 'mosaic effect' ${ }^{48}$ of potentially having to apply a large number of national laws to the communication, it might be suggested that the 'realm' of social media (as a whole or in part) could itself be conceptualised as a distinct political community or social ordering. To put this another way, if the law of defamation is partially involved in protecting public interests, could we consider adopting a non-territorial state conception of the relevant 'public' within which a reputation exists and has allegedly been damaged $?^{49}$

This idea perhaps risks echoing the apparently misplaced idealism of 1990s assertions of a distinct and de-territorialised 'law of cyberspace'. ${ }^{50}$ But it is not entirely far-fetched. The Rome II Regulation (which as noted above excludes defamation) already anticipates the possibility that parties might, at least in limited circumstances, themselves choose the law which governs a claim in tort between them. ${ }^{51}$ The Hague Principles on Choice of Law in International Commercial Contracts permit the parties to choose non-state law to govern their contractual relations, ${ }^{52}$ embracing the growing recognition (or at least discussion) of 'transnational law' ${ }^{53}$ Loosely combining these considerations, it is not unimaginable that the contract for a social media platform might require the parties to agree that their communications would be governed by a particular standard of free speech, which would not

\footnotetext{
48 See Mills, 'The Application of Multiple Laws' (n 30).

49 See more generally David S Ardia, 'Reputation in a Networked World: Revisiting the Social Foundations of Defamation Law' (2010) 45 Harv CR-CLL Rev 261; Cedric Ryngaert and Mark Zoetekouw, 'The End of Territory? The Re-Emergence of Community as a Principle of Jurisdictional Order in the Internet Era' (2014) Working Paper <http://ssrn.com/abstract=2523354> accessed 3 June 2016.

50 See eg David R Johnson and David G Post, 'Law and Borders - The Rise of Law in Cyberspace' (1996) 48 Stan L Rev 1367. See Andrew Murray, Chapter XX in this volume for further discussion of this work.

${ }^{51}$ Art 14.

${ }^{52}$ Art 3 <www.hcch.net/index_en.php?act=conventions.text\&cid=135> accessed 3 June 2016.

${ }^{53}$ See generally eg Peer Zumbansen, Günther Handl and Joachim Zekoll (eds), Beyond Territoriality.

Transnational Legal Authority in an Age of Globalization (Brill 2012).
} 
necessarily need to be tied to the standard of any particular state. This approach would also potentially be supported by the idea, examined previously in this chapter, that tort law may be principally concerned with regulating an existing legal relationship - with or without a crossborder element, such a relationship may not be centred around any state legal or social order, but around the social (and potentially legal and contractual) order established within the social media platform. Private arbitral tribunals already commonly regulate disputes over contracts which are governed by non-state law, ${ }^{54}$ and arbitral awards based on the application of non-state law are readily enforced by the English courts. ${ }^{55}$

Social media organisations are in fact already heavily engaged in regulating aspects of free speech themselves, particularly through censorship of communications deemed to be offensive, and do not necessarily apply any national law in doing this. It is, for example, notable that Facebook regulates content through application of a set of 'Community Standards' which 'aim to find the right balance between giving people a place to express themselves and promoting a welcoming and safe environment for everyone ${ }^{56}$ - replicating the function of national law rather than referring or deferring to it. ${ }^{57}$ A prominent nongovernmental organisation focused on the rights of internet users has expressed the concern

\footnotetext{
${ }^{54}$ Special online dispute resolution processes have also been developed in some cases, for example, by eBay and Amazon - see further eg Thomas Schultz, 'Private Legal Systems: What Cyberspace Might Teach Legal Theorists' (2007) 10 Yale J L \& Tech 151; David P Baron, 'Private Ordering on the Internet: The eBay Community of Traders' (2002) 4 Bus \& Pol 245.

${ }^{55}$ Note the Arbitration Act 1996, s 46; see, eg, Deutsche Schachtbau- und Tiefbohrgesellschaft mbH at al $v$ The Government of the State of R'as Al Khaimah and The R'as Al Khaimah Oil Company ('the Rakoil Case') [1987] 2 All ER, pp 769-84 (reversed on other grounds at [1990] 1 AC 295); Channel Tunnel Group Ltd v Balfour Beatty Constructions Ltd [1993] AC 334; Musawi v RE International (UK) Ltd [2007] EWHC 2981 (Ch); Dallah Real Estate and Tourism Holding Co v Pakistan [2010] UKSC 46. On the possibility of 'non-state law' see further generally Thomas Schultz, Transnational Legality: Stateless Law and International Arbitration (OUP 2014).

${ }^{56}$ Facebook, 'Community Standards' <www.facebook.com/communitystandards/?letter> accessed 3 June 2016.

${ }^{57}$ See ibid: 'Because of the diversity of our global community, please bear in mind that something that may be disagreeable or disturbing to you may not violate our Community Standards'. The terms and conditions on Facebook also provide that they are governed by the laws of the State of California, and contain an exclusive jurisdiction agreement in favour of 'the U.S. District Court for the Northern District of California or a state court located in San Mateo County' (Facebook, 'Statement of Rights and Responsibilities' <www.facebook.com/legal/terms> accessed 3 June 2016). The agreement does not purport, however, to define the law or forum applicable to disputes between users.
} 
that "Facebook has become a sort of parallel justice with its own rules that we cannot fully understand." ${ }^{58}$ Free speech on Facebook, in a practical sense, is thus regulated not principally through private law defamation claims, but through removal of content based on application of Facebook's own (somewhat unclear) quasi-administrative standards. ${ }^{59}$

It is by no means suggested that this idea of a non-state public online realm, with its own standards of speech protection, is unproblematic. For example, if it is to be based on contractual consent then its application will be limited to situations in which the claimant and defendant to proceedings are both members of the same social media platform, within which the claimant's reputation has been damaged. Perhaps more critically, this idea would seem to constitute (or at least recognise) a potentially problematic transfer of regulatory power from the public sphere to the private. It is not self-evident that the benefits of recognising non-state community standards (such as avoiding apparently arbitrary or multiple territorial laws) outweigh the seemingly alarming consequences of the fact that this would empower corporations such as Facebook or Twitter to determine the limits of free speech on their platforms (or rather enhance the extent to which they already do so in reality), displacing norms which may be generated through more participatory and democratic processes. ${ }^{60}$ One concern is that the rules on a social media platform or their enforcement could readily become politicised, although it must also be remembered that national law control over social

\footnotetext{
58 Leo Kelion, 'Facebook Wipes Page Saying Soldiers Should Be Murdered' (BBC News, 8 April 2014) <www.bbc.co.uk/news/technology-26938007> accessed 3 June 2016, quoting a representative of 'Squaring the Net' (La Quadrature du Net: Internet and Libertés <www.laquadrature.net/> accessed 3 June 2016).

${ }^{59}$ Facebook, 'Community Standards' (n 55) provides that 'We allow you to speak freely on matters and people of public interest, but remove content that appears to purposefully target private individuals with the intention of degrading or shaming them'. They appear to take a different approach, however, in relation to 'public figures', providing that 'We permit open and critical discussion of people who are featured in the news or have a large public audience based on their profession or chosen activities', although also noting that 'We remove credible threats to public figures, as well as hate speech directed at them - just as we do for private individuals'.

${ }^{60}$ See generally eg Evgeny Morozov, The Net Delusion: How Not to Liberate the World (Penguin 2012).
} 
media does not in any way guarantee its depoliticisation - as events in Russia in relation to VKontakte (Russia's most popular social media platform) may appear to suggest. ${ }^{61}$

Given this range of concerns, this chapter does not advocate the recognition of non-state norms to govern cross-border defamation in place of national laws, let alone claim that existing positive law quite allows for this type of analysis. But non-state private regulation of social media is already taking place far more commonly and effectively than regulation by national law and institutions, and lawyers and legal academics ignore such realities at their peril. The problems and the example discussed above highlight that the issues posed by crossborder defamation on social media are deeper than merely practical problems - they are potentially problems which challenge our very idea of a political community within which a reputation may exist and speech may be regulated, and they are worth taking seriously.

\section{Conclusions}

As choice of law in tort has developed through UK statutory reform and European harmonisation, choice of law in defamation has been left behind, continuing to be subject to the traditional common law double-actionability rule. In part this is because there remain doubts about the appropriateness of adopting any rule which approaches choice of law in defamation purely as a matter of private law, without recognising the important public significance of the regulation of free speech in a political community. In part it is also because agreeing on any new rule has proven extremely difficult. Even offline, adopting any

\footnotetext{
61 See eg 'Russian Social Network Founder Says He Has Been Fired' (BBC News, 22 April 2014) <www.bbc.co.uk/news/technology-27113292> accessed 3 June 2016 ('The founder of Russia's most popular social network site says he has been fired and that allies of President Putin have taken over his site.'); Marc Scott, 'Mail.ru Takes Full Ownership of VKontakte, Russia's Largest Social Network' (The New York Times, 16 September 2014) <http://dealbook.nytimes.com/2014/09/16/mail-ru-takes-full-ownership-of-vkontakte-russiaslargest-social-network/> accessed 3 June 2016.
} 
territorial rule to determine the law which governs a cross-border claim in defamation appears problematic, whether the tort is determined to be located at the place of damage or the place of the wrongful act. The former potentially leads to a multiplicity of laws and the risk that any given law will be over-projected through injunctive relief, and thus a 'race to the bottom' in terms of free speech protection. The latter leads to a single law which is likely to favour the publisher, and thus a 'race to the top' in terms of free speech protection, and the over-projection of that law into other political communities. Online, the problems are multiplied, as the internet may spread regulation as readily as it spreads information, and communication is less likely to be targeted or directed to any particular audience. The 'solution' to these problems appears, in the final analysis, to belong to the realm of policy rather than technique, based on whether the risk of damaging free speech is considered to outweigh the risk of harm to private reputations. The difficulties in resolving these questions mean that defamation online is a twenty first century problem which remains regulated by a nineteenth century rule - but it might be argued, perhaps surprisingly, that this is appropriately so.

The addition of social media to this issue creates not only further complexity and practical problems, but also potentially a more fundamental challenge. As people increasingly maintain and rely on personal and business connections online, it may be that the application of territorial rules to connect their communications or reputations to national legal orders becomes increasingly difficult and arbitrary. The more challenging suggestion this raises is that, at least in some circumstances, the relevant political community which defamation law should seek to protect is an online community, not a territorial state community. Exactly how such a legal order could be constructed or recognised - or indeed whether it should be at all is a question whose full exploration is beyond the scope of this chapter. But if social media 
platforms are, as it is often claimed, changing the way we live our lives, so that our social organisation is ordered around online groups rather than within territorial 'neighbourhood' social circles, then we should take seriously the proposition that this could also change the way we identify and regulate ourselves within legal orders, perhaps bringing choice of law into the twenty-first century world of social media. 